\title{
LUMBAR SPINE SYNOVIAL CYST: A CASE SERIES REPORT AND REVIEW OF SURGICAL STRATEGIES
}

\author{
Bruno Splavski ${ }^{1,2,3}$, Ante Rotim ${ }^{4}$, Ivan Brumini ${ }^{5}$, Ivan Koprek $^{6}$, Domagoj Gajski ${ }^{1,5}$, \\ Boris Božić ${ }^{1,5}$ and Krešimir Rotim ${ }^{1,2,5}$
}

${ }^{1}$ Department of Neurosurgery, Sestre milosrdnice University Hospital Centre, Zagreb, Croatia;

${ }^{2}$ Josip Juraj Strossmayer University of Osijek, School of Medicine, Osijek, Croatia;

${ }^{3}$ Josip Juraj Strossmayer University of Osijek, School of Dental Medicine and Health, Osijek, Croatia;

${ }^{4}$ Department of Neurosurgery, Dubrava University Hospital, Zagreb, Croatia;

${ }^{5}$ University of Applied Health Sciences, Zagreb, Croatia;

${ }^{6}$ Department of Neurosurgery, Varaždin General Hospital, Varaždin, Croatia

\begin{abstract}
SUMMARY - Lumbar spine synovial cysts are benign growths adjoining the facet joints that may induce low back pain, lumbar radiculopathy and neurological deficit. However, they are not well defined concerning their origin, cause and pathology, as well as available treatment strategies. The scope of different surgical procedures includes image-guided epidural steroid injection, direct cyst puncture by percutaneous epidural needle, spinal canal decompression and cyst resection, and spinal bone fusion with/without instrumentation. Hereby, we report institutional experience and discuss surgical strategies of lumbar spine synovial cyst treatment. Presenting symptoms, imaging findings and outcomes were retrospectively analyzed in 15 patients with lumbar spine synovial cyst, operated on during a one-year period. The leading presenting symptom was lumbar radicular pain, while the most commonly involved vertebral level was L5-S1. In a great majority of patients, a single-level interlaminectomy and cyst resection were performed. Most patients recovered without postoperative neurological and functional deficit, as well as surgery-related complications. No poor outcome was noticed in our series. Concerning our results and literature review, the optimal management for patients with symptomatic lumbar synovial cyst has to be highly personalized, which is essential to achieve a favorable outcome. Nonetheless, the best treatment strategy has yet to be affirmed.
\end{abstract}

Key words: Lumbar spine synovial cyst; Treatment strategies; Surgical management; Outcome

\section{Introduction}

Spinal synovial cysts are benign expansive cystic structures attached to the facet joint epithelium-lined capsule enclosing synovial fluid. Baker was the first to describe their formation in 1885 , referring to the kneejoint ${ }^{1}$. In a considerable number of cases, lumbar syno-

Correspondence to: Bruno Splarski, $M D, P h D$, Department of Neurosurgery, Sestre milosrdnice University Hospital Centre, Vinogradska c. 29, HR-10000 Zagreb, Croatia

E-mail: splavuno@gmail.com

Received July 19, 2019, accepted August 16, 2019 vial cysts may produce back and radicular pain, as well as lumbar radiculopathy and, on occasions, a neurological deficit ${ }^{2}$. Thus far, controversy goes on concerning their origin, cause, pathology and optimal treatment modalities.

Synovial cysts of the lumbar spine may be clinically dormant or asymptomatic and found incidentally, when the cysts are small ${ }^{3}$. However, epidural cystic growth into the spinal canal may produce compression of the adjacent neural structures and may be accountable for related presenting symptoms of which low back/radicular pain, radiculopathy and neurological deficit of various degree are most usual ${ }^{2}$. 
Radiographically, the cyst is seen on spinal computed tomography (CT) scans as a calcified cystic lesion adjoining to a facet joint, which is commonly affected with arthropathy ${ }^{4}$. Hence, spinal magnetic resonance imaging (MRI) is a high-quality diagnostic tool of choice because of its ability to demonstrate the cyst relation to dural sac and neural structures of the spinal canal ${ }^{4-7}$.

Symptomatic lumbar synovial cysts that are resistant to conservative treatment should be operated on ${ }^{8}$. Cyst resection and spinal canal decompression by interlaminectomy and medial facetectomy with/without spinal bone fusion and instrumentation continues to be suitable surgical strategies to avoid cyst relapse and to preserve spinal stability ${ }^{8-13}$.

Hereby, we present a single-institution case series and discuss surgical strategies for the management of lumbar spine synovial cysts, based on the literature review and our experience gained during the last few years.

\section{Patients and Methods}

A case series of adult patients with symptomatic lumbar spine synovial cysts operated on during a oneyear period, between January and December 2017, was retrospectively analyzed.

Presenting symptoms and lumbar spine MRI showing a cystic epidural mass adjacent to the facet join with $\mathrm{T}-1$ hypointensity and T-2 hyperintensity, and considerable dural sac and nerve root compression represented an indication for surgery.

All patients underwent clinical follow-up at varying times after surgery during a period of up to one year. The investigated variables were low back/radicular pain, functional disability, and management outcome. Visual analog scale (VAS) ${ }^{14,15}$ was employed to assess the intensity of pain in low back and legs at hospital admission, discharge and follow-ups. Oswestry Disability Index (ODI) was used to estimate preoperative, postoperative and follow-up functional disabili$\mathrm{ty}^{16}$. It divides patients into five categories according to the percentage of disability they have reported (minimal - ODI 0-20\%; moderate - ODI 21\%-40\%; severe - ODI 41\%-60\%; crippled - ODI 61\%-80\%; and bedbound - ODI 81\%-100\%). Odom criteria dividing accomplishment of surgery into excellent, good, fair and poor were utilized to assess the management outcome at follow-ups ${ }^{17}$.

The difference between investigated variables was statistically analyzed. Spearman's correlation (p) was used as a nonparametric measure to test statistical dependence between two variables. On post-hoc analysis, t-test for dependent variables was used. The level of significance was set at $\mathrm{p} \leq 0.01$. The SPSS for Windows, version 16.0 (SPSS Inc., Chicago, Illinois, USA) was used on statistical data analysis.

\section{Results}

The study group consisted of 15 patients operated on for symptomatic lumbar synovial cysts, eleven of them females and four males, mean age $56.3 \pm 11.1$ years (Table 1). The leading presenting symptom was low back/radicular pain of various intensity, which was recorded in all patients from our series. It was characterized as excruciating pain (VAS 8-10) in 12 out of 13 (92.3\%) patients, while one (7.7\%) patient reported moderate presenting pain (VAS 5). Pain intensity in low back and legs measured by VAS decreased in most

Table 1. Demographic characteristics of the sample

\begin{tabular}{|l|l|l|l|}
\hline & $\mathrm{n}$ & $\begin{array}{l}\text { Age } \\
(\text { mean } \pm \mathrm{SD})\end{array}$ & $\%$ \\
\hline Male & 4 & $52.5 \pm 17.5$ & 26.7 \\
\hline Female & 11 & $57.7 \pm 8.5$ & 73.3 \\
\hline Total & 15 & $56.3 \pm 11.1$ & 100 \\
\hline
\end{tabular}

patients, from the preoperative mean of 9.1 points to 1.8 points immediately after surgery and to 3.6 points at follow-ups ranging from 6 months to one year postsurgery. The difference between the intensity of preoperative and postoperative, as well as between preoperative and follow-up low back/radicular pain (VAS) was statistically significant $(\mathrm{p}<0.001)$ (Table 2, Fig. 1a,b).

Other presenting symptoms consisted of sensory changes in the legs and feet including numbness and paresthesia that were recorded in nine $(60.0 \%) \mathrm{pa}-$ tients, while lower extremity motor weakness (unilateral paresis) was recorded in five (33.3\%) patients and urinary incontinence in one (6.6\%) patient (Table 3).

Spinal MRI T-1 and T-2 weighted sagittal and axial reformations were done in all patients prior to surgery (Fig. 2). 
Table 2. Intensity of pain (VAS) according to time of assessment

\begin{tabular}{|l|l|l|}
\hline VAS & Mean \pm SD & $\mathrm{p}$ \\
\hline Before surgery & $9.1 \pm 1.3$ & \\
\hline At hospital discharge & $1.8 \pm 1.8$ & 0.001 \\
\hline At follow-up & $3.6 \pm 3.3$ & \\
\hline
\end{tabular}

VAS = visual analog scale

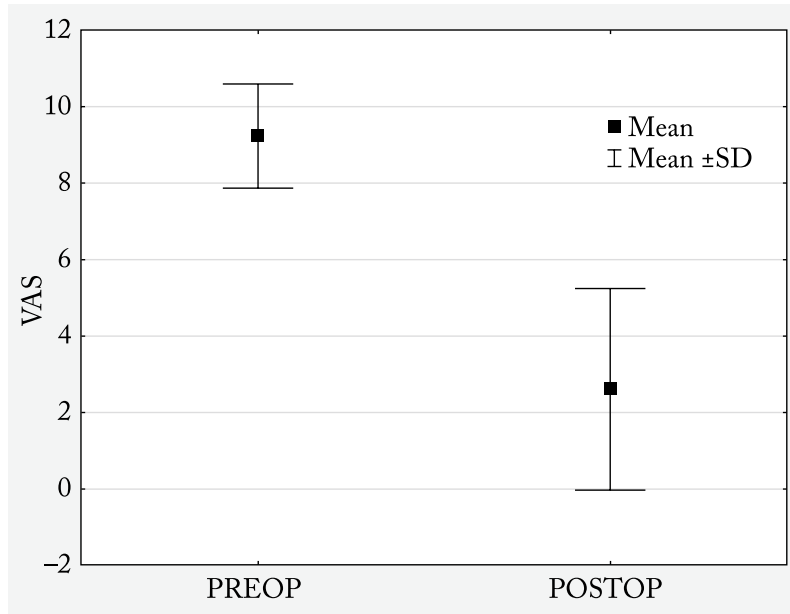

$1 \mathrm{a}$

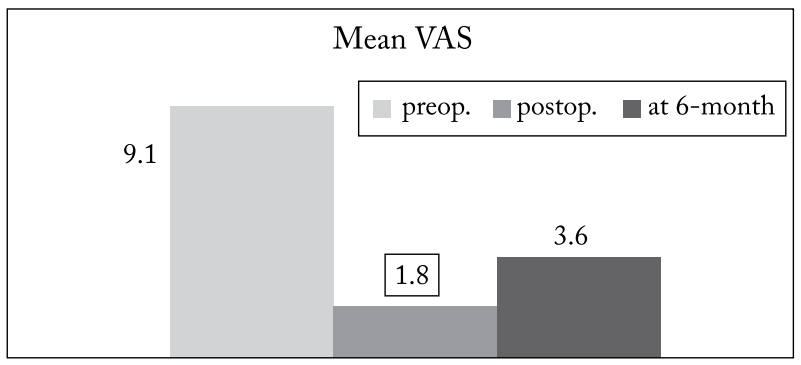

$1 \mathrm{~b}$

Fig. 1 (a) Correlation between the intensity of preoperative and postoperative low back/radicular pain (visual analog scale, VAS); (b) correlation among the intensity of preoperative, postoperative and follow-up low back/radicular pain (VAS).

The most commonly involved vertebral level was L5-S1, which was recorded in eight (53.3\%) patients, followed by L4-L5 in six (40.0\%) patients and L2-L3 in one (6.6\%) patient (Table 4). Four (26.6\%) patients had the same level lumbar disc herniation accompanying the cyst, while in one (6.6\%) patient bilateral foraminal stenosis was found.
Table 3. Other presenting symptoms and clinical signs

\begin{tabular}{|l|l|l|}
\hline & $\mathrm{n}$ & $\%$ \\
\hline $\begin{array}{l}\text { Sensory changes in legs and feet } \\
\text { including numbness and paresthesia }\end{array}$ & 9 & 60.01 \\
\hline Lower extremity motor weakness & 5 & 33.33 \\
\hline Urinary incontinence & 1 & 6.66 \\
\hline
\end{tabular}

One patient underwent epidural steroid injection (ESI) prior to surgery due to obstinate radicular pain, but no percutaneous cyst puncture was performed.

In 14 out of 15 (93.3\%) patients, single-level interlaminectomy and cyst resection was carried out (Fig. 3). In one patient, laminectomy was performed due to bilateral foraminal stenosis. One patient had interlaminectomy previously performed due to disc herniation and underwent repeated surgery because of re-herniation and cyst formation. In this patient, reinterlaminectomy, facetectomy and single-level posterior bone fusion and transpedicular instrumentation were performed.

Intraoperative histopathology of the samples removed was consistent with fibrinous tissue suggestive of synovial cyst in all patients.

In all patients, postoperative spinal $\mathrm{T}-1$ and $\mathrm{T}-2$ weighted MRI demonstrated complete decompression of the dural sac and lumbar vertebral canal after resection of the synovial cyst.

All but one patient were successfully operated on and recovered fully with no postoperative neurological and functional deficit. In the remaining patient who presented with back pain, motor weakness and urinary incontinence, neurological deficit persisted post-surgery, while the nociceptive pain was reduced. No postoperative cyst recurrence was noticed in any patient.

The level of functional disability, measured by ODI scoring, diminished following surgery. Preoperative scoring indicated moderate disability (ODI 21\%-40\%) in ten (66.6\%) patients, severe (ODI 41\%-60\%) and crippled (ODI 61\%-80\%) disability in two (13.33\%) patients each, and bed-bound disability (ODI 81\%$100 \%$ ) in one (6.66) patient. Postoperative scoring disclosed minimal disability (ODI 0-20\%) in 13 (86.6\%) and moderate disability (ODI $21 \%-40 \%$ ) in the remaining two (13.4\%) patients. Follow-up scoring taken in the period between 6 and 12 months after surgery showed minimal disability (ODI $0-20 \%$ ) in ten (66.6\%) and moderate disability (ODI $21 \%-40 \%$ ) in 


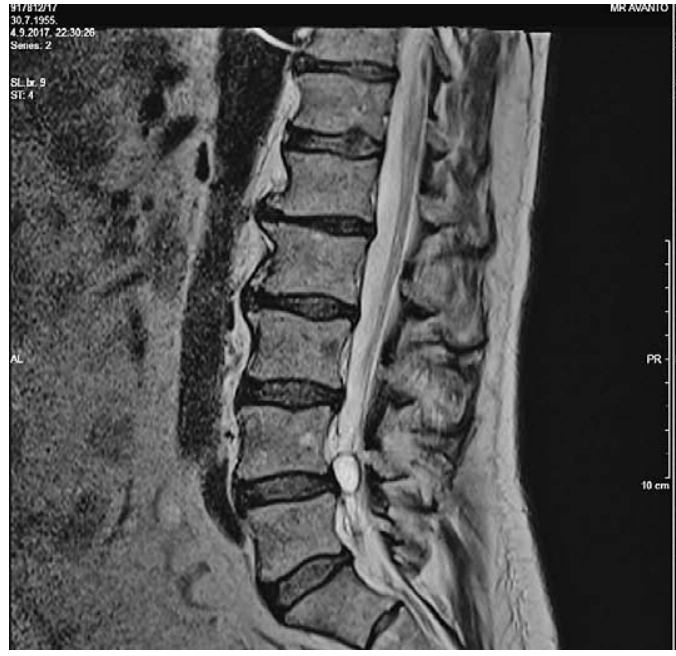

a

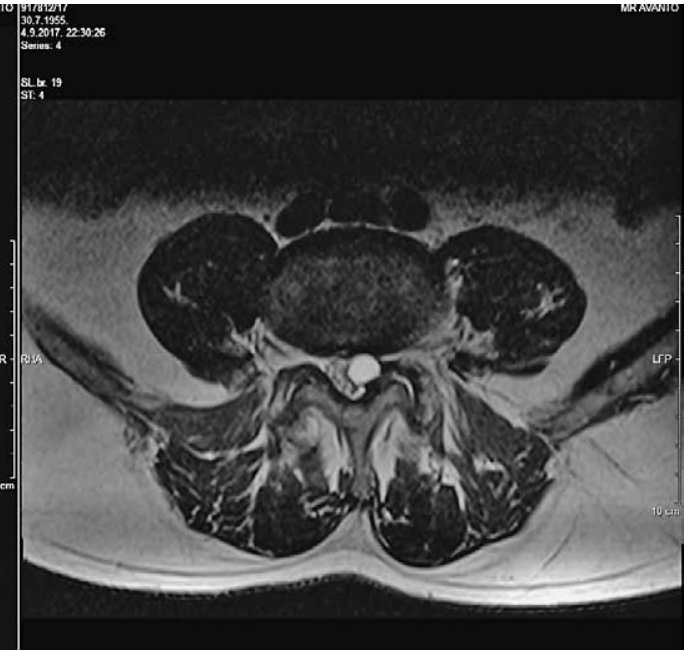

$\mathrm{b}$

Fig. 2. Sagittal (a) and axial (b) reformations of spinal T-2 weighted MRI showing left facet joint synovial cyst of $L 4 / 5$ level obstructing the left lateral recess with compression of the dural sac.

Table 4. Vertebral level affected

\begin{tabular}{|l|l|l|}
\hline & $\mathrm{n}$ & $\%$ \\
\hline L2-L3 & 1 & 6.66 \\
\hline L4-L5 & 5 & 33.33 \\
\hline L5-S1 & 9 & 60.01 \\
\hline
\end{tabular}

Table 5. Functional disability (ODI) according to time of assessment

\begin{tabular}{|l|l|l|}
\hline ODI \% & $\mathrm{n}$ & $(\%)$ \\
\hline Before surgery & & \\
\hline Moderate (21-40) & 10 & 66.66 \\
\hline Severe (41-60) & 2 & 13.33 \\
\hline Crippled (61-80) & 2 & 13.33 \\
\hline Bed-bound (81-100) & 1 & 6.66 \\
\hline At hospital discharge & & \\
\hline Minimal (0-20) & 13 & 86.66 \\
\hline Moderate (21-40) & 2 & 13.33 \\
\hline At follow-up & & \\
\hline Minimal (0-20) & 10 & 66.66 \\
\hline Moderate (21-40) & 5 & 33.33 \\
\hline
\end{tabular}

ODI = Oswestry Disability Index

the remaining five (33.4\%) patients (Fig. 4). The difference in the percentage of preoperative, postoperative and follow-up disability was statistically significant $(\mathrm{p}=0.01)$ (Table 5).

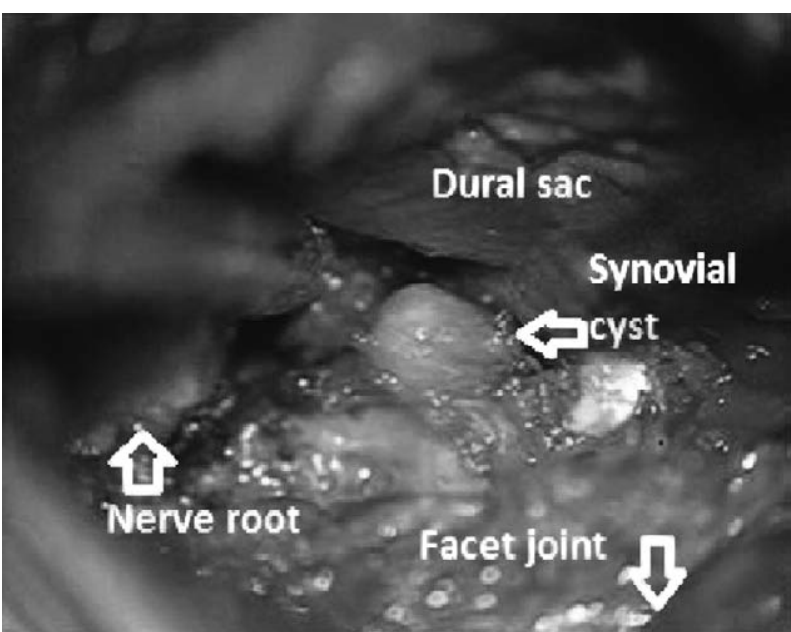

Fig. 3. Intraoperative resection of lumbar synovial cyst (relationship between the cyst and the surrounding structures such as the nerve root, facet joint and dural sac is well visualized).

Table 6. Outcome at follow-up (Odom)

\begin{tabular}{|l|l|l|}
\hline & $\mathrm{n}$ & $\%$ \\
\hline Excellent & 9 & 60.01 \\
\hline Good & 4 & 26.66 \\
\hline Fair & 2 & 13.33 \\
\hline Poor & 0 & 0 \\
\hline Total & 15 & 100 \\
\hline
\end{tabular}


According to Odom criteria, the outcome at follow-ups was excellent in nine (60\%), good in four (26.7\%), and fair in two (13.3\%) patients. No poor outcome was noticed in our series (Table 6). No complications related to surgery including cerebrospinal fluid (CSF) leak and and/or local or systemic infections, and no cyst relapses were recorded at follow-up ranging up to one year post-surgery.

\section{Discussion}

Epidemiologically, lumbar cysts usually appear during the sixth decade of life with a slight female predominance ${ }^{7,18,19}$, which is consistent with our results, since the patients in our series were predominantly females and middle-aged. A good number of authors report painful radiculopathy as a major clinical sign accompanying the cyst progression ${ }^{13,18}$. Accordingly, the leading presenting symptom in our series was unilateral or bilateral low back/radicular pain of various intensity due to the cyst compression effect.

For the most part, the cysts occur in lumbar spine with a preference to L4-5 as the most affected level ${ }^{3-5,8,20}$. They may be situated unilaterally or bilaterally, at single or multiple levels ${ }^{2,8,19}$. The most commonly involved vertebral level in our series was L5-S1, which is somewhat inconsistent with literature data (Table 4) (3-5,8 $^{\text {. }}$

Computed tomography scanning and spinal MRI are the most appropriate imaging modalities for characterization of synovial cysts and preoperative planning $^{8}$. On spinal MRI, a cyst appears as a well-circumscribed, extra-dural compressive lesion adjacent to a facet joint, having greater signal intensity than the surrounding CSF on T-2 weighted images (Fig. 2) ), $^{5}$. Accordingly, all patients from our series underwent the same diagnostic MRI protocol, which was found fairly reliable.

There is a plethora of different treatment strategies for the management of lumbar spine synovial cysts. However, total cyst excision via small flavectomy as the least invasive approach should be considered surgical therapy of choice ${ }^{13,21-23}$. Spinal fusion is also considered an option when spinal instability is concerned to avoid cyst recurrence ${ }^{10}$. The main surgical strategy in our series consisted of spinal canal decompression using facet-sparing minimally invasive techniques followed by total cyst excision (Fig. 3). One patient in whom the facet joint had to be partially resected by medial facetetcomy and who had previously been operated on due to lumbar disc herniation, underwent mono-segmental bone fusion and transpedicular instrumentation to evade possible postoperative lumbar spine instability.

Postoperative pain intensity in the low back and legs considerably decreased in most patients in our series. The difference between the intensity of preoperative and postoperative, as well as between preoperative and follow-up low back/radicular pain (VAS) was statistically significant (Table 2, Fig. 1a,b).

The level of functional disability was markedly diminished from moderate to minimal disability following surgery. The difference in percentage of preoperative, postoperative and follow-up disability was statistically significant (Table 5).

The outcomes were excellent or good in almost all of the patients in our series, which means that the majority of them were able to cope with most of their living activities following surgery (Table 6).

The above findings justified spinal decompression and the appropriate synovial cyst removal as a surgical option bringing satisfactory results.

In conclusion, it seems that the best surgical management should be modified according to the symptoms and radiological findings, as well as functional status of the spine and patient comorbidities. Hence, surgery has to be highly personalized and individually designed for each particular patient, which is a prerequisite for satisfactory outcome to be expected.

At the end of this paper, we would like to address some limitations coming from its retrospective character and small number of patients in our series. Thus, supplementary research on a broader sample is mandatory to sustain our results.

\section{References}

1. Baker WM. On the formation of synovial cysts in the leg in connection with disease of the knee-joint 1877. Clin Orthop. 1994;299:2-10.

2. Bureau NJ, Kaplan PA, Dussault RG. Lumbar facet joint synovial cyst: percutaneous treatment with steroid injections and distention-clinical and imaging follow-up in 12 patients. Radiology. 2001;221(1):179-85. doi: 10.1148/radiol.2211010213.

3. Yarde WL, Arnold PM, Kepes JJ, O’Boynick PL, Wilkinson SB, Batnitzky S. Synovial cysts of the lumbar spine: diagnosis, surgical management, and pathogenesis. Report of eight cases. Surg Neurol. 1995;43(5):459-64. 
4. Liu SS, Williams KD, Drayer BP, et al. Synovial cysts of the lumbosacral spine: diagnosis by MR imaging. AJR Am J Roentgenol. 1990;154(1):163-6.

5. Jackson DE Jr, Atlas SW, Mani JR, Norman D. Intraspinal synovial cysts: MR imaging. Radiology. 1989;170(2):527-30.

6. Knox AM, Fon GT. The appearances of lumbar intraspinal synovial cysts. Clin Radiol. 1991;44(6):397-401.

7. Lyons MK, Atkinson JL, Wharen RE, Deen HG, Zimmerman RS, Lemens SM. Surgical evaluation and management of lumbar synovial cysts: the Mayo Clinic experience. J Neurosurg. 2000;93(Suppl 1):53-7.

8. Khan AM, Girardi F. Spinal lumbar synovial cysts. Diagnosis and management challenge. Eur Spine J. 2006;15(8):1176-82.

9. Boviatsis EJ, Stavrinou LC, Kouyialis AT, et al. Spinal synovial cysts: pathogenesis, diagnosis and surgical treatment in a series of seven cases and literature review. Eur Spine J. 2008;17(6): 831-7.

10. Bydon M, Papadimitriou K, Witham T, Wolinsky JP, Sciubba $\mathrm{D}$, Gokaslan Z, et al. Treatment of spinal synovial cysts. World Neurosurg. 2013;79(2):375-80. doi: 10.1016/j.wneu.2012.08.016.

11. Bydon A, Xu R, Parker SL, McGirt MJ, Bydon M, Gokaslan ZL, Witham TF. Recurrent back and leg pain and cyst reformation after surgical resection of spinal synovial cysts: systematic review of reported postoperative outcomes. Spine J. 2010;10(9):820-6. doi: 10.1016/j.spinee.2010.04.010.

12. Khan AM, Synnot K, Cammisa FP, Girardi FP. Lumbar synovial cysts of the spine: an evaluation of surgical outcome. J Spinal Disord Tech. 2005;18(2):127-31.

13. Trummer M, Flaschka G, Tillich M, Homann CN, Unger F, Eustacchio S. Diagnosis and surgical management of intraspi- nal synovial cysts: report of 19 cases. J Neurol Neurosurg Psychiatry. 2001;70(1):74-7.

14. Huskisson EC. Measurement of pain. Lancet. 1974;2:1127-31.

15. McCormack HM, Horne DJ, Sheather S. Clinical applications of visual analogue scales: a critical review. Psychol Med. 1988; 18:1007-19.

16. Fairbank JC, Pynsent PB. The Oswestry Disability Index. Spine (Phila Pa 1976). 2000;25(22):2940-52.

17. Odom GL, Finney W, Woodhall B. Cervical disc lesions. JAMA. 1958;166:23-8.

18. Howington JU, Connolly ES, Voorhies RM. Intraspinal synovial cysts: $10-y e a r$ experience at the Ochsner Clinic. J Neurosurg. 1999;91(2 Suppl):193-9.

19. Pirotte B, Gabrovsky N, Massager N, Levivier M, David P, Brotchi J. Synovial cysts of the lumbar spine: surgery-related results and outcome. J Neurosurg. 2003;99(1 Suppl):14-9.

20. Freidberg SR, Fellows T, Thomas CB, Mancall AC. Experience with symptomatic spinal epidural cysts. Neurosurgery. 1994;34 (6):989-93.

21. Bruder M, Cattani A, Gessler F, Droste C, Setzer M, Seifert V, Marquardt G. Synovial cysts of the spine: long-term follow-up after surgical treatment of 141 cases in a single-center series and comprehensive literature review of 2900 degenerative spinal cysts. J Neurosurg Spine. 2017;27(3):256-67. doi: 10.3171/2016.12.SPINE16756.

22. Denis DR, MD, Hirt D, Shah S, Lu DC, Holly LT. Minimally invasive surgery for lumbar synovial cysts with coexisting degenerative spondylolisthesis Int J Spine Surg. 2016;10:37. doi: 10.14444/3037.

23. Sehati N, Khoo LT, Holly LT. Treatment of lumbar synovial cysts using minimally invasive surgical techniques. Neurosurg Focus. 2006;20(3):e2.

Sažetak

\title{
SINOVIJALNA CISTA SLABINSKE KRALJEŽNICE: PRIKAZ NIZA SLUČAJEVA I PREGLED STRATEGIJA KIRURŠKOG LIJEČENJA
}

\author{
B. Splavski, A. Rotim, I. Brumini, I. Koprek, D. Gajski, B. Božić i K. Rotim
}

Sinovijalne ciste slabinske kralježnice benigne su ekspanzivne tvorbe smještene u blizini fasetnih zglobova koje mogu uzrokovati bol u donjim leđima, lumbalnu radikulopatiju i neurološki deficit. Međutim, ishodište i uzroci njihovog nastanka kao i moguće strategije liječenja ovakvih cista još su nedovoljno poznati. Raspon različitih postupaka kirurškog liječenja uključuje radioskopski navođenu epiduralnu steroidnu infiltraciju, perkutanu punkciju ciste epiduralnom iglom, dekompresiju kralježničnog kanala i uklanjanje ciste te spinalnu koštanu fuziju s instrumentacijom ili bez nje. U ovom radu prikazujemo naša iskustva u liječenju slabinskih sinovijalnih cista i raspravljamo različite strategije njihovog kirurškog liječenja. Retrospektivno su analizirani simptomi, nalazi dijagnostičkih pretraga i uspješnost liječenja u 15 operiranih bolesnika sa slabinskom sinovijalnom cistom tijekom jednogodišnjeg razdoblja. Vodeći prezentirajući simptom bila je slabinska radikularna bol, a najčešće zahvaćena razina bila je ona na L5-S1. Jednorazinska interlaminektomija i resekcija ciste učinjena je u velike većine bolesnika koji su se uspješno oporavili bez poslijeoperacijskog neurološkog i funkcijskog deficita, kao i bez nastanka komplikacija. Temeljem naših rezultata i pregledom literature zaključujemo da optimalno liječenje bolesnika sa sinovijalnom cistom slabinske kralježnice treba biti usmjereno svakom pojedinom bolesniku kako bi se osigurao uspješan ishod. Istodobno, najbolja strategija kirurškog liječenja još nije dovoljno potvrđena.

Ključne riječi: Slabinska sinovijalna cista; Strategije liječenja; Kirurško liječenje; Ishod 